\title{
UNIVERSITIES AND SOCIETY: PROBLEMS OF COOPERATION AND DEVELOPMENT
}

\author{
Volodymyr Ryabchenko \\ Doctor of Philosophy (Dr. Hab.), Head of the Department of Leadership \\ and Institutional Development of Higher Education, Institute of Higher Education \\ of the National Academy of Educational Sciences of Ukraine \\ e-mail: rvivan@ukr.net, orcid.org/0000-0001-6404-1045
}

\section{Summary}

The research relies on the assumption that universities in their activity and development significantly depend on the state and evolutionary stage of society in which they function. Universities respond to the demand of degree-seeking students for educational services that is generated within society. Thus, the state and evolutionary stage of society depend on implemented political and economic institutions. The problem of that sort of dependence emerges full-blown in the countries with hybrid and authoritarian regimes. A hybrid regime of the oligarchical kind has gained a foothold in Ukraine. The vast majority of studies of activities and development of Ukrainian universities are limited to intra-institutional format without critical analysis of the primary causes of these problems, which are rooted in the social context, that is methodologically incorrect. Therefore, the purpose and tasks of the research involve identifying and clarifying the central problems of the cooperation and development of universities and society that are produced by a hybrid regime of the oligarchical type. Nowadays, Ukrainian society doesn't take on the role of the key stakeholder in the advancement of its universities due to economic backwardness, a lack of civilized competitive environment and ample employment opportunities upon the availability of diplomas of higher education ignoring requirements for actual proficiency of their owners. That sort of the state of the Ukrainian society is caused by a lack of the rule of law, monopolization of its political and economic spheres, the use of the state for private benefits, civil society's failure to effectively and successfully secure from the abuses of authorities in their current activity. To overcome the problems restraining the progress of Ukrainian society and its universities, it is necessary to demonopolize the political and economic spheres, disengage business from politics, and create a civilized competitive environment through establishing the rule of law.

Keywords: Ukraine, political regime, higher education, competence, competitiveness, human capital, reforming, civilized competitive environment.

DOI: https://doi.org/10.23856/4514

\section{Introduction}

Research relevance is driven by the need to optimize the cooperation of universities and society that affects the prospect and progress of their development amidst modern technogenic civilization. The above is explained by the fact that university graduates ensure both scientific-technical progress and socio-economic development as a whole because the diplomas of higher education allow them to get admission to relevant social statuses, including power, in the social hierarchy. The system of social relations, which can either contribute to a country's successful development or hinder or even block this development, depends on 
authorities. The problem of that sort of dependence emerges full-blown in the countries with hybrid and authoritarian regimes. Among the twenty-nine countries of the former "Soviet-Socialist bloc", only ten managed to become transformed into established and semi-established democracies. Other ten formed hybrid regimes, and nine ex-USSR countries kept authoritarianism (Drachuk, 2020).

Ukraine represents a hybrid regime of the oligarchical type, which gained a foothold in the nineties of the last century and has blocked its further civilized development. Due to the predominance of such a political regime, Ukraine lags far behind the counties, which have morphed into established democracies, and is progressively sliding into the Third World countries. Lagging disrupts the enhancement of Ukrainian higher education as an integrated factor of its competitiveness. In turn, poor higher education obtained by a wide circle of alumnus hinders social advancement, and thus, the country's competitiveness. The beforementioned actualizes the study of root causes which give rise to the vicious circle of destructive interaction of universities and society in the countries with hybrid regimes.

The analysis of publications shows that the overwhelming majority of studies of the development of Ukrainian universities is limited to intra-institutional format without critical analysis of primary causes of these problems, which are rooted in the social context. The studies, which are reduced to the subject field of pedagogy when handling the problems of personality development of degree-seeking students, their competitive expertise without concern over the factors of modern Ukrainian society creating these problems, have a specific tendency to disengagement.

The purpose of the research is to identify and clarify the central problems of the cooperation and development of universities and society that are generated by a hybrid regime of the oligarchical type.

Methodology. The research relies on the assumption that universities in their activity and development significantly depend on the state and evolutionary stage of society in which they function. Universities respond to the demand of degree-seeking students for educational services that is generated within society. Thus, the state and evolutionary stage of society depend on implemented political and economic institutions. The author uses philosophical and general scientific research methods, in particular, dialectical method, systems approach, and socio-philosophical analysis.

\section{General characteristics of the current state of Ukrainian society}

Universities and other higher education institutions dialectically interact with their society, and thus, are directly dependent on its state and development. Amidst the noosphere in the period of the fourth industrial revolution, society and its country are less likely to become competitive and successful in their civilizational progress without sound higher education represented by a wide circle of university graduates. However, there are no logical grounds to hope for the successful growth and competitiveness of universities in a society that falls into decline or lags in development. The mentioned society can't perform a mission of the key stakeholder in the context of the advancement of its higher education. Until it becomes that sort of stakeholder, there will be no quality of its higher education that would meet modern world requirements. It refers to the entire higher education system, not the top universities which are outnumbered or the best university graduates who are not a majority as well.

Such interdependence - in which a pivotal role belongs to society - is characterized by the poor performance of intra-institutional higher education reforms, which took place in 
Ukraine during the last two decades in the context of the Bologna Process. During that period, Ukraine overhauled the higher education system that essentially approximated it to the relevant standards and requirements of the European space of higher education in terms of statutory, structural and even conceptual parameters. Nevertheless, the reforms undertaken didn't result in the improved quality of higher education. A lack of international recognition of Ukrainian diplomas of higher education is an integral indicator of the above.

The low quality of Ukrainian higher education is recognized at the official state level. In particular, S. Kvit, Head of the National Agency for Higher Education Quality Assurance, said the following in that regard: "Dear colleagues! We have to clarify what conditions will make Ukrainian higher education sound and competitive on the international scene. Is it like that now? In other words, are we satisfied with the current state of affairs? If one omits "great strength of great words", we have to admit honestly: no, we are not" (Kvit, 2019).

The Draft of Higher Education Development Strategy of Ukraine for 2021-2031 points at the pivotal role of society in the development of universities: "The general problem of the higher education system is that Ukrainian society doesn't generate demand for higher education as an institution and primary resource of domestic development that, along with the massification of higher education, leads to the deformation of the educational process and underperformance of a higher education institution (HEI). ... Limited employment prospects after HEI graduation and sometime low-quality education encourage the most intelligent, talented and ambitious young people to enroll at foreign HEIs. ... A lack of demand for natural and technical education (except for computer sciences) results in the distortion of the number of student and enrollee under subject areas. This is due to weakness and the country's economic focus on raw materials. A small number of high-tech industries does not create sufficient demand and does not guarantee the employment of future professionals. At the same time, there is a gap between staff training structure and demands of a labor market" (Stratehiia rozvytku vyshchoi osvity..., 2020).

The major problem is the extensive economy of Ukraine that is maintained through the unreasonable and ineffective use of productive forces on account of the society's well-being and contrary to sustainable development. Audit of the Ukrainian economy until 2030 (n.d), which was a basis for the elaboration and approval of the National Economic Strategy by the Cabinet of Ministers of Ukraine, confirms the mentioned state by referring to the following indicators:

- Nowadays, the real GDP in Ukraine is lower than 30 years ago. In terms of GDP (nominal) per capita, it lags behind Poland, which was not ahead of Ukraine in 1990, by 4.5 times. If the Ukrainian GDP increases like today - by 3\% - it will need half a century to achieve Polish GDP per capita. However, the Polish economy is not going to give up-it will keep its progress. Having more substantial resources (human, natural, territorial etc.), Ukraine fell behind the pace of Poland by 50 years over three decades. Upon such an economic growth rate, there is a prospect to pursue with a constant lagging (Audyt ekonomiky..., n.d.).

- The Ukrainian economic situation is pulling away from the leaders of the world community; it is progressively sliding into the Third World countries, which serve as row appendage to more productive ones. The level of added value, which raised by $4 \%$ in the industry, indicates an unpromising tendency. Indeed, in Latvia, the Czech Republic and Turkey, this indicator increased by 185\%, 91\% and 248\%, respectively (Audyt ekonomiky..., n.d.: 9). In the service industry that gained in Ukraine amidst industrial manufacturing collapse, added value has hardly raised and is 1284 USD per employee. Thus, this figure is 12,566 USD in the Czech Republic, 15339 USD - in Poland, and 15823 USD - in Lithuania (Audyt ekonomiky..., n.d.: 10). 
- "Poor development of the economy led to poor human development and a low living standard for the Ukrainian people (Audyt ekonomiky..., n.d.: 12). Since 1991, Ukraine's population has declined by more than 10 million. It has happened due to the excess of deaths over births and migration. The citizens of Ukraine have better living conditions abroad where they produce much higher added value. "According to conservative estimates, Ukrainians, who have left Ukraine during the years of independence (including their descendants), generate 219 USD billion of gross value added abroad - this is twice as much compared to the gross value added of Ukraine. Following the highest estimates, gross value added produced by the representatives of the Ukrainian diaspora may amount to 1.27 USD trillion that is ten times as high compared to the total gross value added generated annually in Ukraine. The reason for this gap is much higher labor productivity in those countries where Ukrainians emigrate" (Audyt ekonomiky..., n.d.: 16). The above is a direct confirmation of the low level of competitiveness of the Ukrainian economy.

High tech industries didn't become widespread in the economy of Ukraine. "Ukraine is neither mentioned in OECD Country Risk Classification in the context of high-tech industries in the national GDP nor in the Doing Business rankings in terms of high-tech products in the national export. What can illustrate the competitiveness of the national economy more vividly than the above facts?... Nothing else than a low cost of workforce remains, as well as a low cost of natural resources, that benefits not to the country but to moneymakers maintaining the relevant recourses and public servants who allow them to act so. ... In addition to the traditional indicators like production costs per unit of labor and capital inputs, such factors as the number of hi-tech investments, the maturity of science and professional education play a major role in ensuring competitiveness. R\&D investments in Ukraine are $0.4 \%$ while, for instance, in Ireland $-4.3 \%$, in Italy $-3.3 \%$, in the USA $-2.8 \% "$.

The backward economy of Ukraine is decisively confirmed by the ranking of the 50 most in-demand jobs in Ukraine dated 01.01.2021 (Naibilsh zatrebuvani profesii..., 2021). Professions which don't require higher educational attainment prevail in the ranking. Only 11 professions require a university degree: 4 medical, 3 police, 2 teacher posts, an accountant and a local government employee. There is no any profession requiring a degree in industrial production, particularly high-tech. Nowadays, the most in-demand jobs in Ukraine are not related to manufacturing but the service sector. However, this sector of the economy can't make Ukraine, as well as higher education, competitive.

Ukrainian society is socially sick since it is affected by social diseases, which have a system nature and don't localize if there are no adequate mechanisms for localization, neutralization, blocking, and have become chronic. Corruption, incompetence protection, double moral standards, cultivation of cynical pragmatism etc. have the most destructive effect on its development. In Ukraine, the state as a government institution is under the control of civil servants, who use it for their own benefit. The alienation of authorities from the people disintegrates society, and the abuse of powers for their enrichment multiplies internal social patriotism (Riabchenko, 2015: 89-161).

A lack of a civilized competitive environment in Ukrainian society has created unlimited employment opportunities for non-competitive persons in civilized labor markets given the formal availability of a diploma of higher education without regard for their actual expertise. In particular, the above concerns such so-called budget spheres as politics, civil service, law enforcement agencies, fiscal authorities, education, science, health care, etc. These are chiefly those areas of activity that don't generate added value directly; however, the productivity of society heavily relies on the competence of their actors and their proper performance, from politics to public administration. 


\section{Central problems of universities' development}

It is no surprise that most central problems of Ukrainian higher education are predominantly caused by the problems of modern Ukrainian society, namely:

- The financing of higher education doesn't even meet the approximate level which it needs to become competitive in international competitions. This is confirmed by comparative analysis of its actual financing, not nominal based on a share of GDP, with other countries. Compared to other countries worldwide, Ukraine has the lowest expenses per student -860 dollars, while Great Britain - 16. 9 thousand dollars, German - 14.25 thousand dollars, Poland 3.1 thousand dollars (Stratehiia rozvytku..., 2020).

- The lack of robust competition in our society led to the overwhelming cultivation of incompetence protection, which embraces not only the assistance in employing less competent persons compared to other candidates for a particular post but also unjustified dismissal of persons whose expertise level fits the position held. It is manifested in supporting students who are not capable or don't strive to get a high-quality education, and tolerating academic dishonesty, including falsification of academic outcomes etc.

- Ample opportunities cultivated by employment protectionism according to formal features of the availability of a diploma of higher education, not to objective competence to compete with other candidates on a parity basis, generate a great demand in higher education institutions for a diploma of higher education. The demand comprised the mechanism of academic corruption: a student gets required grades regardless of his academic excellence. The need for diplomas of higher education of those subjects who are not capable to get it independently or are lazy to achieve it creates a proposal that is cheerfully provided by higher education institutions which make profit from incompetence protectionism (Riabchenko, 2020: 90).

- It is little surprise that such an earning spread out in the context of the least resource specialties, which need nothing but study books, academic staff and study space. This is evidenced by the statistics available from the Analysis which was discussed at the meeting of the National Security and Defense Council of Ukraine. Thus, in 2019, $57.5 \%$ of the total graduates of universities, academies and institutes represented the least resource-demanding specialties (administration and management $-21.5 \%$, education /pedagogy $-13.2 \%$, law $-7.8 \%$, social and behavioral sciences $-5.4 \%$, culture and art $-2.7 \%$, humanities $-2.4 \%$, public management and administration $-2.1 \%$, international relations $-1.0 \%$, journalism $-0.5 \%$ (Analiz stanu systemy, 2020: 11).

- Most students obtain a degree in management and administration and public management and administration that is more than forty per cent of the least resource-demanding specialties and almost a quarter of the total. This confirms the aspiration of Ukrainian youth to hold managerial posts in Ukrainian society and unwillingness to make efforts to gain expertise in high-tech specialties. The prevalence of humanities in the context of specialists' training is caused by both fewer expenditures for maintaining academic activities and an easier way - in comparison with natural-technical subject areas - to get a diploma of higher education as a pro forma pass to social ladders in the lack of civilized competition.

- As a result, such a demand for nominal higher education led to the overgrowth of licensed volume for admission of students to the relevant specialties and the increase of domestic higher education institutions, which become called universities, that didn't meet real genuine demands. For instance, there was one university in Kyiv until the 90s, and there are now at least forty HEIs, the names of which contain the word "university". From 1990 to the present, the number of technical secondary schools (tekhnikums) and vocational schools has 
decreased from 742 to 338 , and the number of students has decreased from 757 to 173.6 thousand - almost by 4.5 times. The maximal reduction of vocational schools happened over the last 15 years. This is primarily associated with a lack of funding for the activities of resource educational institutions that was transferred to the local budgets of the administrative units where they operated. In addition to the above, a strong reason for the mentioned reduction was the supernormal growth of higher education services, which took place between 1995 and 2010 and created easy access for many high school graduates to obtain a higher education diploma. Over the specified period, the number of universities, academies, institutes increased from 149 to 339 , and the number of applicants increased from 881.3 to 2372.5 thousand - by 2.7 times. Over the last decade, the number of higher education institutions decreased to 281 and the number of students - to 1256,1 because of demographic crises (Analiz stanu systemy..., 2020: 4). Thus, it resulted in the fact that the overall licensed volume of admission to higher education institutions of Ukraine was more than high school graduates. Most higher education institutions faced a lack of competition among applicants that made the formation of a qualified student body impossible. One can't hope for high-quality higher education without a qualified student body.

- A low prestige of a teaching career and the loss of human resources adversely influence the advancement of competitiveness of academic staff. Salaries of the academic staff of Ukrainian HEIs are much lower than in the top countries. In the 2017/2018 academic year, the annual salary of the most skilled personnel - professors - is 7 thousand dollars in Ukraine, while in Great Britain - 116.7 thousand dollars, German - 99.5 thousand dollars; of teachers (lecturers) -4.7 thousand dollars in Ukraine, while in Great Britain is 54.2 thousand dollars, Germany -58.8 thousand dollars (Stratehiia rozvytku..., 2020: 19).

- A low prestige of academic activity and a steady decline of education financing don't motivate Ukrainian youth to pursue science. From 2010 to 2019, the number of postgraduate students in Ukraine decreased by $19.5 \%$ ( 23 thousand persons), the number of enrolled postgraduate students dropped in 2019 by $22.8 \%$ (6780 persons) compared to 2010 . The total number of postdoctoral students was reduced by $24.2 \%$ (937 persons), enrollees - by $9.7 \%$ (435 persons). A low salary level, a lack of social guarantees and opportunities for the realization of personal potential cause an outflow of talented youth from domestic HEIs and scientific establishments (Stratehiia rozvytku..., 2020: 20-21).

\section{Root causes of cooperation and development of universities and society}

The system of social relations and the regime, which keeps this system, chiefly generate Ukrainian society's lagging behind the civilized development and ensuing advancement problems of its universities and other higher education institutions. According to the 2021 annual report "Nations in Transit" of the US human rights organization "Freedom House", a hybrid regime of the oligarchical type prevails in Ukraine (Drachuk, 2019). This explains its backwardness in socio-economic progress compared to Poland and the Baltic region, which became the rule-of-law states through introducing inclusive political and economic institutions in their societies. In Ukraine, there was the transformation of extractive institutions of the Soviet regime into the extractive institutions of the oligarchical type.

Having embarked on such a path of socio-economic transformation, Ukraine was trapped in a vicious circle that is progressively leading it in deterioration, not in progress in its civilizational development. That is likely to remain in effect as long as Ukraine breaks free of this circle. D. Acemoglu and D. Robinson explain that a vicious circle is formed by extractive political 
and economic institutions while inclusive institutions shape an integrity circle that contributes to successful civilized development and the nation's prosperity.

First, the above is proved by the mentioned grim statistics that visualizes the devastating stagnation of Ukraine in the world competitions of civilized development. Second, it illustrates the iron law of oligarchy, the relentless effect of which is the decline of nations; D. Acemoglu and D. Robinson interpret it as follows: "An iron law of oligarchy, a particular image of a vicious circle, means that new leaders overthrowing old ones with promises of radical change bring nothing but more of the same" (Acemoglu, Robinson, 2019: 315). By referring to the German sociologists R. Michels who defined the relevant law, they explain, "The internal logic of oligarchies, and in fact of all hierarchical organizations, is that, argued Michels, they will reproduce themselves not only when the same group is in power, but even when an entirely group takes control" (Acemoglu, Robinson, 2019: 314).

The following warning is extremely relevant to Ukraine: "If extractive institutions create great inequality in society, provide leaders with vast fortune and limitless power, there will be many persons interested in fighting for the seizure of control over the state and institutions. Moreover, extractive institutions not only break the way for the succeeding regime, that is more extractive, but also give rise to constant struggle and civil wars. Indeed, the latter cause more severe human sufferings and destroy everything a weak state centralization of countries achieved. This often results in slipping into unlawful acts, state destruction and political chaos shattering all hopes for economic prosperity..." (Acemoglu, Robinson, 2019: 320).

The mentioned tendency is confirmed by the two revolutions of 2004 and 2014 when one group of authorities was deprived of control over the state that was granted to others using the Ukrainian people, who were about to lose confidence in incumbent authorities. However, the status quo of the hybrid regime, which uses the state as its property, has remained unaltered up to the present day. Ukraine doesn't have a powerful civil society which would control the government after conducted revolutions and secure from abuses of its actors in power. Uncontrollability, unaccountability and irresponsibility of authorities are a source of systemic corruption, which blocks the productive development of society, demoralizes it and multiplies social parasitism.

The weakness of civil society in Ukraine is driven by a lack of the strong working class and socio-economic dependence of most people on the state and authorities which control it. This sort of dependence encompasses sources of financial support of citizens of Ukraine. For most folks, a salary or pension is the only source. The reasons for such dependence are monopolization of the political and economic realms of Ukrainian society, a lack of the rule of law and a civilized competitive environment. The above hinders development and productive implementation of human capital.

\section{Proposals for overcoming problems of the development of Ukrainian society and its universities}

Overcoming problems of the development of modern Ukrainian society should start with eliminating root causes, which trigger them, and continue with a cause-and-effect chain, as follows:

- To introduce inclusive political and economic institutions through demonopolizing the political and economic spheres of Ukrainian society and disengaging business from politics.

- To establish the rule of law, the characteristic criterion of which is equality of all citizens regardless of their status before the law. 
- To shape a civilized competitive environment within society that would include the mechanisms of positive social selection.

- The mechanisms of positive social selection through civilized competition must contribute to society's self-purification from corruption and other types of social parasitism, and thus, its recovery.

- A civilized competitive environment will create opportunities for a strong middle class, which will require the use of competitive production technologies for its development, entailing adequate expertise for their maintenance.

- Pro forma diplomas of higher education amidst a civilized competitive environment will lose their social importance, which they currently have in terms of a relevant post held in a social hierarchy.

- The demand for competitive competence becomes topical among the citizens of Ukraine; exclusively competitive higher education institutions can guarantee its satisfaction.

- The demand for competitive competence results in optimizing domestic HEIs through positive selection, not through administrative way, like now, that is implicitly associated with corruption risks and unjust decisions.

- The net result is that the model of optimal cooperation and development of Ukrainian society and its higher education institutions will function productively.

- To accelerate such a necessary transformation of modern Ukrainian and its productive cooperation of universities and other higher education institutions, ones must carry out positive changes of domestic higher education of the intra-institutional nature:

- It is essential to keep reforming the entire domestic system of higher education, approximating it to standards and requirements of the European space of higher education in the statutory-procedural, structural and informative context.

- To ensure the financial autonomy of domestic HEIs.

- To create an effective model of forecasting qualifications in the labor market. To introduce a system for monitoring workforce demand and proposals in the labor market.

- To improve the system of the competitive entrance to HEI to select motivated persons who are capable of obtaining higher education.

- Ukrainian higher education institutions must become the centers and hubs of universal human values. Such a task suits students motivated to gain competitive expertise, rectors and their teams, who don't rely on the values of survival tactics but follow the development strategy of their academic environment that would compete with West European universities in terms of opportunities for specialists' training.

- To implement the system of electronic monitoring, which is a basis of the ranking of domestic universities upon the criteria of alumni's employment and career progress.

- To introduce the mechanisms of effective governance in managing higher education institutions which must democratize their social environment that should liberate the initiative of the subjects of their activity, increase personal responsibility for progress made and promote the development of personal potential.

\section{Conclusions}

In the period of the fourth industrial revolution, the country cannot become competitive without sound higher education since their progress is interdependent. However, despite the importance of higher education in this dialectical cooperation, it cannot independently make the country competitive given that its economy and society are on the wane or hopelessly lag 
in its development compared to the leaders of the world community. Thus, the non-competitive country cannot have competitive higher education.

A basis of society and key to its advancement is the economy that cannot be competitive in those industries which are not available in its structure or are not technologized and developed contemporarily. There is no reason to accuse higher education of not training competitive specialists in high-tech industries, which the domestic economy lacks. The competitiveness of higher education is supported by its competitive financing.

Higher education, as a social institution, responds to students' demand for educational services that is generated within society. If the student community is not capable or is not motivated to gain expertise meeting modern world requirements, then one should not hope for competitive higher education in such a society. Unlimited employment opportunities in society upon the availability of diplomas ignoring competitive expertise of their owners motivate the general public to obtain poor education.

The quality of higher education primarily depends on the expertise of academic staff, students, educational programs and material support of educational and scientific activities. However, the importance of all factors is neutralized without capable and motivated students to obtain competence competitive in the civilized markets. Thus, the actualization of student personality to obtain competitive knowledge is a determinant for the development of a higher education institution. It is impossible to form a qualitative student body without entrance competition.

Ukraine is in urgent need of competitive specialists and a genuine national elite, which relies on the democratic values and statism worldview, in order to become a competitive and prosperous country - in terms of public well-being - and equal among best countries of the world community. Education is a fundamental component or a groundwork of human capital. The more qualitative education is, the higher level of the competitiveness of human capital is.

Nowadays, Ukrainian society doesn't fulfill the role of the key stakeholder in the development of its universities due to economic backwardness, a lack of civilized competitive environment and ample employment opportunities if there are pro forma diplomas of higher education without the requirements for actual competence of their owners. The mentioned state of Ukrainian society is caused by the lack of the rule of law, monopolization of its political and economic areas, use of the state for private interests, civil society's failure to effectively and successfully secure from the abuses of authorities in their current activities.

To overcome the problems which hinder the advancement of Ukrainian society and its universities, it is essential to demonopolize the political and economic areas, disengage business from politics, and form a civilized competitive environment through establishing the rule of law.

\section{References}

Acemoglu, D., \& Robinson, D. (2019). Chomu natsii zanepadaiut: Pokhodzhennia vlady, bahatstva ta bidnosti [Why nations fail: The origins of power, prosperity and poverty]. Kyiv: Nash format. [in Ukrainian]

Analiz stanu systemy vyshchoi osvity ta derzhavnoho zamovlennia na pidhotovku fakhivtsiv, naukovykh, naukovo-pedahohichnykh ta robitnychykh kadriv, na pidvyshchennia kvalifikatsii ta perepidhotovku kadriv u 2020 rotsi u konteksti natsionalnoi bezpeky [Analysis of the higher education system and state order for training specialists, scientific, academic and labor force, 
for advanced training and retraining in 2020 amidst national security] (2020). Aparat Rady natsionalnoi bezpeky i oborony Ukrainy. Kyiv. [in Ukrainian]

Audyt ekonomiky Ukrainy 2030. [Audit of the Ukrainian economy for 2030]. (n.d.). Kabinet Ministriv Ukrainy. Retrieved from: https://nes2030.org.ua/docs/doc-audit.pdf [in Ukrainian] Danylyshyn, B. (12.06.2019). Yak Ukraini buduvaty konkurentospromozhnu ekonomiku [The way Ukraine should build the competitive economy]. https://www.ukrinform.ua/rubric-economy/2719877-ak-ukraini-buduvati-konkurentospromoznu-ekonomiku.html [in Ukrainian]

Drachuk, S. (6 travnia, 2020). Demokratychnyi reitynh Ukrainy deshcho zris, ale pered neiu stoiat vyklyky v dotrymanni demokratii - Freedom House [The democratic ranking of Ukraine somewhat increased, but it faces the challenges of observing democracy - Freedom House]. Radio svoboda. Retrieved from:https://www.radiosvoboda.org/a/freedom-house-nations-intransit/30594646.html

Kvit, S. (2019). Yakisna vyshcha osvita [Qualitative higher education]. Vystup na Mizhnarodnii konferentsii. "Rozbudova systemy zabezpechennia yakosti vyshchoi osvity v Ukraini», 11-12 chervnia 2019, KNTEU. Retrieved from:http://education-ua.org/ru/articles/1343-yakisna-vishcha-osvita-vistup-na-mizhnarodnij-konferentsiji-rozbudova-sistemi-zabezpechennya-yakosti-vishchoji-osviti-v-ukrajini-11-12-chervnya-2019-knteu

Naibilsh zatrebuvani profesii v Ukraini 01.01.2021 [Top in-demand jobs in Ukraine dated 01.01.2021]. Retrieved from:http://www.futureskills.org.ua/ua/news/67 (accessed: 13.01.2021). Riabchenko, V. (2020). Protektsionizm nekompetentnosti v ukrainskomu suspilstvi yak chynnyk demotyvatsii studentiv u zdobutti nymy yakisnoi vyshchoi osvity [Protectionism of the incompetence of Ukrainian society as a factor in demotivating students to obtain qualitative higher education]. Zbirnyk naukovykh prats IV Vseukrainskoi naukovo-praktychnoi konferentsii. Osobystist studenta ta sotsiokulturne seredovyshche universytetu v suspilnomu konteksti. Kyiv. Retrieved from:https://ihed.org.ua/wp-content/uploads/2020/07/IV_Vseukr.konf_18-05-2020_ Zbirnyk.pdf

Riabchenko, V.I. (2015). Vyshcha shkola Ukrainy v zahalnotsyvilizatsiinomu konteksti: sotsialno-filosofskyi analiz z pozytsii svitohliadno-kompetentnisnoho pidkhodu : monohrafia [Higher education of Ukraine in the general civilizational context: socio-philosophical analysis from the perspective of the belief-competence approach: a monograph]. Kyiv: Fitosotsiotsentr. [in Ukrainian]

The Ministry of Education and Science of Ukraine (2020) Stratehiia rozvytku vyshchoi osvity Ukrainy na 2021-2031 roky [Higher Education Development Strategy of Ukraine for 2021-2031]. Retirved from: http://www.reform.org.ua/proj_edu_strategy_2021-2031.pdf [in Ukrainian] 